\title{
Effect of added zinc in diets with ractopamine hydrochloride on growth performance, carcass characteristics, and ileal mucosal inflammation mRNA expression of finishing pigs ${ }^{1,2}$
}

\author{
C. B. Paulk,* D. D. Burnett,* M. D. Tokach,* J. L. Nelssen,* S. S. Dritz, $\dagger$ \\ J. M. DeRouchey, ${ }^{*}$ R. D. Goodband,* G. M. Hill, \$. D. Haydon, $§$ and J. M. Gonzalez*3
}

\begin{abstract}
*Department of Animal Sciences and Industry, $†$ Department of Diagnostic Medicine/Pathobiology, College of Veterinary Medicine, Kansas State University, Manhattan 66506; \$Department of Animal Science, College of Agriculture and Natural Resources, Michigan State University, East Lansing 48824; §Elanco Animal Health, Greenfield, IN 46140
\end{abstract}

\begin{abstract}
Two experiments were conducted to determine the effects of increasing the dietary $\mathrm{Zn}$ content on growth performance, carcass characteristics, plasma $\mathrm{Zn}$, and ileal mucosal inflammation mRNA expression of finishing pigs fed diets containing ractopamine $\mathrm{HCl}$ (RAC; Elanco Animal Health, Greenfield, IN). In Exp. 1, 312 pigs $(327 \times 1050$; PIC, Hendersonville, TN; $94 \mathrm{~kg} \mathrm{BW}$ ) were used in a $27-\mathrm{d}$ study. There were 2 pigs per pen and 26 pens per treatment. Treatments included a corn-soybean meal diet (control; $0.66 \%$ standardized ileal digestible [SID] Lys); a diet (0.92\% SID Lys) with $10 \mathrm{mg} / \mathrm{kg}$ RAC; and the RAC diet plus 50, 100, or $150 \mathrm{mg} \mathrm{Zn/kg} \mathrm{from}$ $\mathrm{ZnO}$ or $50 \mathrm{mg} \mathrm{Zn} / \mathrm{kg}$ from a $\mathrm{Zn}$ AA complex (ZnAA; Availa-Zn; Zinpro, Eden Prairie, MN). All diets also contained $83 \mathrm{mg} \mathrm{Zn} / \mathrm{kg}$ from $\mathrm{ZnSO}_{4}$ in the trace mineral premix. Pigs fed the RAC diet without added $\mathrm{Zn}$ had increased $(P<0.05)$ ADG, G:F, HCW, carcass yield, and loin weight compared with pigs fed the control diet. Increasing $\mathrm{Zn}$ from $\mathrm{ZnO}$ in diets containing RAC tended to increase (linear, $P=0.067$ ) G:F and loin weight (quadratic, $P=0.064)$. Pigs fed diets with $50 \mathrm{mg} \mathrm{Zn} / \mathrm{kg}$ from $\mathrm{ZnAA}$ tended to have increased $(P=$ $0.057)$ ADG compared with pigs fed the RAC diet. In Exp. 2, 320 pigs $(327 \times 1050$; PIC; $98 \mathrm{~kg} \mathrm{BW})$ were
\end{abstract}

used in a 35-d study. There were 2 pigs per pen and 20 pens per treatment. Treatments included a control diet (0.66\% SID Lys); a diet ( $0.92 \%$ SID Lys) with $10 \mathrm{mg} /$ $\mathrm{kg} \mathrm{RAC}$; or the RAC diet plus 75, 150, and $225 \mathrm{mg} \mathrm{Zn} /$ $\mathrm{kg}$ from $\mathrm{ZnO}$ or $\mathrm{ZnAA}$. All diets also contained $55 \mathrm{mg}$ $\mathrm{Zn} / \mathrm{kg}$ from $\mathrm{ZnSO}_{4}$ from the trace mineral premix. Pigs fed the RAC diet had increased $(P<0.05)$ ADG, G:F, $\mathrm{HCW}$, loin depth, percentage lean, and liver weight compared with pigs fed the control diet. No Zn level or source effects or level $\times$ source interactions were observed for growth performance. A Zn level $\times$ source interaction (quadratic, $P=0.007$ ) was observed in liver $\mathrm{Zn}$ concentrations. This resulted from liver $\mathrm{Zn}$ concentrations plateauing at $150 \mathrm{mg} \mathrm{Zn/kg}$ when $\mathrm{ZnO}$ was supplemented, while there was a linear increase when using $\mathrm{ZnAA}$. Increasing $\mathrm{Zn}$ in diets containing RAC increased (linear, $P<0.05$ ) plasma $\mathrm{Zn}$ on $\mathrm{d} 18$ and 32. The expression of $I L-1 \beta$ was increased $(P=0.014)$ in mucosa of pigs fed the RAC diet compared with those fed the control diet. Expression of $I L-1 \beta$ decreased (linear, $P=0.026$ ) in the mucosa of pigs fed increasing added $\mathrm{Zn}$. In conclusion, adding $\mathrm{Zn}$ to diets containing $\mathrm{RAC}$ resulted in a trend for improved growth performance of pigs in 1 of 2 experiments. Also, additional $\mathrm{Zn}$ increased plasma $\mathrm{Zn}$ and reduced $I L-1 \beta$.

Key words: beta agonist, inflammatory cytokines,

liver, plasma, porcine, zinc amino acid complex, zinc oxide

(C) 2015 American Society of Animal Science. All rights reserved.

J. Anim. Sci. 2015.93:185-196
doi:10.2527/jas2014-8286

\section{INTRODUCTION}

\footnotetext{
${ }^{1}$ Contribution no. 14-012-J from the Kansas Agric. Exp. Stn., Manhattan 66506.

${ }^{2}$ The authors express their appreciation to Elanco Animal Health (Greenfield, IN) for providing partial financial support for this experiment.

${ }^{3}$ Corresponding author: johngonz@ksu.edu

Received July 15, 2014.

Accepted November 9, 2014.
}

Ractopamine HCl (RAC; Paylean; Elanco Animal Health, Greenfield, IN) is a feed additive used in late finishing pig diets to improve growth performance and carcass leanness (Apple et al., 2007). In addition, recent research demonstrates further improved ADG and $\mathrm{G}: \mathrm{F}$ of pigs fed diets containing RAC with added 
$\mathrm{Zn}$ from a $\mathrm{Zn}$ AA complex (ZnAA) compared with those fed added $\mathrm{Zn}$ from an inorganic source $(\mathbf{Z n O}$ or $\mathbf{Z n S O}_{4}$; Patience et al., 2011; Rambo et al., 2012). Fry et al. (2013) also observed increased G:F in pigs fed added $\mathrm{Zn}$ in diets containing RAC. Although previous research demonstrated improvements in performance of pigs fed the $\mathrm{ZnAA}$ or added $\mathrm{Zn}$ in diets containing RAC, the mechanism for these improvements is unknown.

Klasing (1992) suggested that the requirement for $\mathrm{Zn}$ may be greater for optimum immune response compared with growth as $\mathrm{Zn}$ plays an important role in multiple aspects of the immune system (Shankar and Prasad, 1998). Increases in relative protein expression of Interleukin-1 beta (IL-1/) or absolute number of tumor necrosis factor alpha (TNF- $\boldsymbol{\alpha}$ ) can increase intestinal injury leading to a decrease in intestinal barrier function (Ma et al., 2004; Al-Sadi and Ma, 2007). These increases also stimulate macrophages to produce Interleukin- 8 $(\boldsymbol{I L - 8})$, which is responsible for attracting neutrophils to the site of inflammation (Baggiolini and Clark-Lewis, 1992). Bao et al. (2003) determined in vitro that increasing $\mathrm{Zn}$ reduced gene expression of $I L-1 \beta, T N F-\alpha$, and $I L-8$ in the monocyte-macrophage cell line. Therefore, we hypothesized that manipulation of dietary $\mathrm{Zn}$ above the nutritional requirement would modulate intestinal inflammation gene expression and result in improved performance. However, to the best of our knowledge, the response to RAC of gene expression of proinflammatory cytokines has not been studied. Therefore, our objective was to determine the effects of adding various concentrations of $\mathrm{Zn}$ from $\mathrm{ZnO}$ or a $\mathrm{ZnAA}$ (Availa$\mathrm{Zn}$; Zinpro, Eden Prairie, MN) on growth performance, carcass characteristics, plasma and tissue $\mathrm{Zn}$ concentrations, and ileal mucosal inflammation mRNA expression of finishing pigs fed diets containing RAC.

\section{MATERIALS AND METHODS}

\section{General}

The Kansas State University Institutional Animal Care and Use Committee approved the protocol used in these experiments. Both experiments were conducted at the Kansas State University Swine Teaching and Research Center in Manhattan, KS. Pigs were housed in an environmentally controlled finishing building in $1.5 \mathrm{~m}^{2}$ pens containing slatted flooring. Each pen was equipped with a single-hole, dry self-feeder and a nipple waterer to provide ad libitum access to feed and water.

\section{Chemical Analysis}

Samples of each diet were collected from feeders, blended, subsampled, and analyzed at Ward
Laboratories, Inc. (Kearney, NE) for DM (method 934.01; AOAC, 2006), CP (method 990.03; AOAC, 2006), crude fat (method 920.39; AOAC, 2006), CF (method 978.10; AOAC, 2006), and ash (method 942.05; AOAC, 2006).

\section{Experiment 1}

A total of 312 finishing pigs $(327 \times 1050$; PIC, Hendersonville, TN), initially $94 \mathrm{~kg} \mathrm{BW}$, from 2 consecutive groups were used with treatments replicated equally in both groups. Pens of pigs were allotted to 1 of 6 dietary treatments, with either 2 barrows or 2 gilts per pen and 26 pens per treatment. Dietary treatments consisted of a corn-soybean meal-based control diet formulated to contain $0.66 \%$ standardized ileal digestible (SID) Lys, a RAC diet formulated to contain $0.92 \%$ SID Lys and $10 \mathrm{mg} / \mathrm{kg}$ RAC; the RAC diet plus 50, 100, or $150 \mathrm{mg} \mathrm{Zn/kg} \mathrm{from} \mathrm{ZnO}$; or the RAC diet plus $50 \mathrm{mg}$ $\mathrm{Zn} / \mathrm{kg}$ from a ZnAA (Availa-Zn; Zinpro; Table 1). All diets also contained $83 \mathrm{mg} \mathrm{Zn} / \mathrm{kg}$ from $\mathrm{ZnSO}_{4}$ provided by the trace mineral premix. Experimental diets were fed in meal form, and $\mathrm{ZnO}$ or the $\mathrm{ZnAA}$ was added to the RAC diet at the expense of corn. A subsample of experimental diets was collected and analyzed for dietary Zn (Ward Laboratories, Inc.). Samples were prepared using the method outlined by the AOAC (2012) and analyzed using an iCAP 6000 series ICP Emission Spectrometer (Thermo Electron Corporation, Marietta, $\mathrm{OH})$. Total $\mathrm{Zn}$ concentrations were analyzed in duplicate. Analyzed Zn values were 168 and $131 \mathrm{mg} \mathrm{Zn/kg}$ in the control and RAC diets, respectively; 163, 188, and $267 \mathrm{mg} \mathrm{Zn/kg}$ in the diets containing added $\mathrm{ZnO}$; and $185 \mathrm{mg} \mathrm{Zn/kg}$ in the diet containing added ZnAA. Pigs and feeders were weighed on d 0, 14, and 27 to determine $\mathrm{ADG}, \mathrm{ADFI}$, and G:F.

On d 27, all pigs were weighed, individually tattooed, and shipped approximately $2 \mathrm{~h}$ to a commercial harvesting plant (Farmland Foods Inc., Crete, NE). Immediately after harvest, HCW was collected and percent carcass yield was calculated by dividing $\mathrm{HCW}$ by live weight obtained at the farm before transport to the packing plant. Additional carcass measurements were collected only on the second group of pigs. For the second group of pigs, last-rib backfat measurements and boneless loin weights were collected and percentage lean was calculated (NPPC, 2000).

All data were analyzed as a completely randomized design using the MIXED procedure of SAS (SAS Inst. Inc., Cary, NC) with pen as the experimental unit. In addition to treatment, the effects of gender and group were included as random effects. Hot carcass weight was used as a covariate for analyses of backfat thickness, percentage lean, and boneless loin weight. 
Table 1. Diet composition, Exp. 1 (as-fed basis) ${ }^{1}$

\begin{tabular}{|c|c|c|c|c|c|c|}
\hline \multirow[b]{2}{*}{ Item } & \multirow[b]{2}{*}{ Control } & \multirow[b]{2}{*}{$\mathrm{RAC}^{2}$} & \multicolumn{3}{|c|}{$\mathrm{ZnO}, \mathrm{mg} \mathrm{Zn/kg}$} & \multirow{2}{*}{$\frac{\mathrm{ZnAA},{ }^{3} \mathrm{mg} \mathrm{Zn} / \mathrm{kg}}{50}$} \\
\hline & & & 50 & 100 & 150 & \\
\hline \multicolumn{7}{|l|}{ Ingredient, \% } \\
\hline Corn & 84.29 & 73.91 & 73.91 & 73.90 & 73.89 & 73.86 \\
\hline Soybean meal $(46.5 \% \mathrm{CP})$ & 13.65 & 24.00 & 24.00 & 24.00 & 24.00 & 24.00 \\
\hline Monocalcium P $(21 \% \mathrm{P})$ & 0.50 & 0.45 & 0.45 & 0.45 & 0.45 & 0.45 \\
\hline Limestone & 0.90 & 0.90 & 0.90 & 0.90 & 0.90 & 0.90 \\
\hline Salt & 0.35 & 0.35 & 0.35 & 0.35 & 0.35 & 0.35 \\
\hline Vitamin premix ${ }^{4}$ & 0.075 & 0.075 & 0.075 & 0.075 & 0.075 & 0.075 \\
\hline Trace mineral premix ${ }^{5}$ & 0.075 & 0.075 & 0.075 & 0.075 & 0.075 & 0.075 \\
\hline L-Lys $\mathrm{HCl}$ & 0.15 & 0.15 & 0.15 & 0.15 & 0.15 & 0.15 \\
\hline DL-Met & - & 0.015 & 0.015 & 0.015 & 0.015 & 0.015 \\
\hline L-Thr & - & 0.025 & 0.025 & 0.025 & 0.025 & 0.025 \\
\hline $\mathrm{RAC}^{6}$ & - & 0.05 & 0.05 & 0.05 & 0.05 & 0.05 \\
\hline $\mathrm{ZnO}$ & - & - & 0.007 & 0.014 & 0.021 & - \\
\hline $\mathrm{ZnAA}$ & - & - & - & - & - & 0.05 \\
\hline \multicolumn{7}{|l|}{ Calculated analysis, $\%$} \\
\hline $\mathrm{ME}, \mathrm{kcal} / \mathrm{kg}$ & 3,351 & 3,347 & 3,347 & 3,347 & 3,346 & 3,345 \\
\hline $\mathrm{NE}, \mathrm{kcal} / \mathrm{kg}$ & 2,512 & 2,445 & 2,445 & 2,445 & 2,444 & 2,444 \\
\hline SID $^{7}$ Lys, $\%$ & 0.66 & 0.92 & 0.92 & 0.92 & 0.92 & 0.92 \\
\hline Total Lys, \% & 0.75 & 1.03 & 1.03 & 1.03 & 1.03 & 1.03 \\
\hline SID Lys:ME/Mcal & 1.97 & 2.75 & 2.75 & 2.75 & 2.75 & 2.75 \\
\hline $\mathrm{Ca}, \%$ & 0.51 & 0.53 & 0.53 & 0.53 & 0.53 & 0.53 \\
\hline Total P, \% & 0.44 & 0.47 & 0.47 & 0.47 & 0.47 & 0.47 \\
\hline Available P, \% & 0.16 & 0.16 & 0.16 & 0.16 & 0.16 & 0.16 \\
\hline \multicolumn{7}{|l|}{ Analyzed values } \\
\hline $\mathrm{DM}, \%$ & 89.16 & 89.31 & 89.11 & 89.41 & 89.07 & 89.25 \\
\hline $\mathrm{CP}, \%$ & 13.44 & 17.34 & 17.64 & 17.76 & 17.52 & 18.02 \\
\hline Crude fiber, $\%$ & 1.94 & 2.10 & 2.12 & 2.20 & 2.06 & 2.18 \\
\hline Fat, $\%$ & 2.82 & 2.92 & 2.92 & 2.88 & 2.80 & 3.00 \\
\hline Ash, $\%$ & 3.50 & 4.02 & 4.11 & 4.06 & 3.99 & 4.12 \\
\hline $\mathrm{Zn}, \mathrm{mg} \mathrm{Zn} / \mathrm{kg}$ & 168 & 131 & 163 & 188 & 267 & 185 \\
\hline
\end{tabular}

${ }^{1}$ Diets were fed in meal form from d 0 to 27 of the experiment. Basal diets contained $83 \mathrm{mg} \mathrm{Zn} / \mathrm{kg}$ from $\mathrm{ZnSO}_{4}$ provided by the trace mineral premix.

${ }^{2} \mathrm{RAC}=$ ractopamine $\mathrm{HCl}$.

${ }^{3} \mathrm{ZnAA}=\mathrm{Zn}$ AA complex (Availa-Zn; Zinpro, Eden Prairie, MN).

${ }^{4}$ Provided per kilogram of diet: 3,307 IU vitamin A, 413 IU vitamin $\mathrm{D}_{3}, 13 \mathrm{IU}$ vitamin E, $1.3 \mathrm{mg}$ vitamin $\mathrm{K}, 2.5 \mathrm{mg}$ riboflavin, $8.3 \mathrm{mg}$ pantothenic acid, $14.9 \mathrm{mg}$ niacin, and $0.01 \mathrm{mg}$ vitamin $\mathrm{B}_{12}$.

${ }^{5}$ Provided per kilogram of diet: $20 \mathrm{mg}$ Mn from manganese oxide, $83 \mathrm{mg}$ Fe from iron sulfate, $83 \mathrm{mg}$ Zn from zinc sulfate, $8 \mathrm{mg}$ Cu from copper sulfate, $0.15 \mathrm{mg}$ I from calcium iodate, and $0.15 \mathrm{mg}$ Se from sodium selenite.

${ }^{6}$ Provided $10 \mathrm{mg} / \mathrm{kg}$ of RAC (Paylean; Elanco Animal Health, Greenfield, IN).

${ }^{7} \mathrm{SID}=$ standardized ileal digestible.

Contrast statements consisted of 1) control vs. RAC diet, 2) increasing $\mathrm{ZnO}$ linear and quadratic polynomials, 3) RAC diet vs. the ZnAA diet, and 4) $50 \mathrm{mg} \mathrm{Zn/}$ $\mathrm{kg}$ from $\mathrm{ZnO}$ vs. from the $\mathrm{ZnAA}$. Statistical significance was determined at $P<0.05$ and $P$-values falling within $P>0.05$ and $P<0.10$ were considered a trend.

\section{Experiment 2}

A total of 320 finishing pigs $(327 \times 1050$; PIC), initially $98 \mathrm{~kg} \mathrm{BW}$, from 4 consecutive groups were used with treatments replicated equally in all groups. Pens of pigs were randomly allotted to 1 of 8 dietary treatments with either 2 barrows or 2 gilts per pen and 20 replicate pens per treatment. Dietary treatments included a corn-soybean meal-based control diet formulated to $0.66 \%$ SID Lys; a RAC diet formulated to $0.92 \%$ SID Lys and $10 \mathrm{mg} / \mathrm{kg}$ of RAC; and the RAC diet plus 75, 150 , or $225 \mathrm{mg} \mathrm{Zn/kg}$ from either $\mathrm{ZnO}$ or the ZnAA (Table 2). All diets also contained $55 \mathrm{mg}$ $\mathrm{Zn} / \mathrm{kg}$ from $\mathrm{ZnSO}_{4}$ provided by the trace mineral premix. Experimental diets were fed in meal form, and $\mathrm{ZnO}$ or the $\mathrm{ZnAA}$ was added to the RAC diet at the expense of corn. Diets were fed for the last $41 \mathrm{~d}$ before slaughter for group 1 and the last $35 \mathrm{~d}$ for group 2, 3, and 4. Analyzed total $\mathrm{Zn}$ concentrations were 66 and 
Table 2. Diet composition, Exp. 2 (as-fed basis) ${ }^{1}$

\begin{tabular}{|c|c|c|c|c|c|c|c|c|}
\hline \multirow[b]{2}{*}{ Item } & \multirow[b]{2}{*}{ Control } & \multirow[b]{2}{*}{$\mathrm{RAC}^{2}$} & \multicolumn{3}{|c|}{$\mathrm{ZnO}, \mathrm{mg} \mathrm{Zn/kg}$} & \multicolumn{3}{|c|}{$\mathrm{ZnAA},{ }^{3} \mathrm{mg} \mathrm{Zn/kg}$} \\
\hline & & & 75 & 150 & 225 & 75 & 150 & 225 \\
\hline \multicolumn{9}{|l|}{ Ingredient, \% } \\
\hline Corn & 83.06 & 74.24 & 74.23 & 74.22 & 74.20 & 74.17 & 74.10 & 74.03 \\
\hline Soybean meal $(46.5 \% \mathrm{CP})$ & 15.22 & 23.97 & 23.97 & 23.97 & 23.97 & 23.97 & 23.96 & 23.95 \\
\hline Monocalcium P (21\% P) & 0.25 & 0.20 & 0.20 & 0.20 & 0.20 & 0.20 & 0.20 & 0.20 \\
\hline Limestone & 0.75 & 0.78 & 0.78 & 0.78 & 0.78 & 0.78 & 0.78 & 0.78 \\
\hline Salt & 0.35 & 0.35 & 0.35 & 0.35 & 0.35 & 0.35 & 0.35 & 0.35 \\
\hline Vitamin premix ${ }^{4}$ & 0.075 & 0.075 & 0.075 & 0.075 & 0.075 & 0.075 & 0.075 & 0.075 \\
\hline Trace mineral premix ${ }^{5}$ & 0.075 & 0.075 & 0.075 & 0.075 & 0.075 & 0.075 & 0.075 & 0.075 \\
\hline L-Lys $\mathrm{HCl}$ & 0.15 & 0.15 & 0.15 & 0.15 & 0.15 & 0.15 & 0.15 & 0.15 \\
\hline DL-Met & - & 0.015 & 0.015 & 0.015 & 0.015 & 0.015 & 0.015 & 0.015 \\
\hline L-Thr & - & 0.025 & 0.025 & 0.025 & 0.025 & 0.025 & 0.025 & 0.025 \\
\hline Phytase $^{6}$ & - & - & - & - & - & - & - & - \\
\hline $\mathrm{RAC}^{7}$ & - & 0.05 & 0.05 & 0.05 & 0.05 & 0.05 & 0.05 & 0.05 \\
\hline $\mathrm{ZnO}$ & - & - & 0.010 & 0.021 & 0.031 & - & - & - \\
\hline $\mathrm{ZnAA}$ & - & - & - & - & - & 0.075 & 0.150 & 0.225 \\
\hline \multicolumn{9}{|l|}{ Calculated analysis, $\%$} \\
\hline $\mathrm{ME}, \mathrm{kcal} / \mathrm{kg}$ & 3,361 & 3,357 & 3,357 & 3,357 & 3,356 & 3,355 & 3,352 & 3,350 \\
\hline $\mathrm{NE}, \mathrm{kcal} / \mathrm{kg}$ & 2,302 & 2,269 & 2,268 & 2,268 & 2,268 & 2,267 & 2,265 & 2,263 \\
\hline SID $^{8}$ Lys, $\%$ & 0.70 & 0.92 & 0.92 & 0.92 & 0.92 & 0.92 & 0.92 & 0.92 \\
\hline Total Lys, \% & 0.79 & 1.03 & 1.03 & 1.03 & 1.03 & 1.03 & 1.03 & 1.03 \\
\hline SID Lys:ME/Mcal & 2.08 & 2.74 & 2.74 & 2.74 & 2.74 & 2.74 & 2.74 & 2.74 \\
\hline $\mathrm{Ca}, \%$ & 0.41 & 0.44 & 0.44 & 0.44 & 0.44 & 0.44 & 0.44 & 0.44 \\
\hline Total P, \% & 0.39 & 0.42 & 0.42 & 0.42 & 0.42 & 0.42 & 0.42 & 0.42 \\
\hline Available P, \% & 0.21 & 0.21 & 0.21 & 0.21 & 0.21 & 0.21 & 0.21 & 0.21 \\
\hline \multicolumn{9}{|l|}{ Analyzed values } \\
\hline $\mathrm{DM}, \%$ & 10.60 & 10.60 & 10.34 & 10.39 & 10.52 & 10.24 & 10.12 & 10.19 \\
\hline $\mathrm{CP}, \%$ & 89.41 & 89.41 & 89.66 & 89.62 & 89.48 & 89.77 & 89.88 & 89.82 \\
\hline Crude fiber, \% & 14.45 & 18.15 & 18.15 & 18.75 & 18.00 & 18.05 & 17.65 & 18.10 \\
\hline Fat, $\%$ & 1.90 & 2.00 & 2.00 & 2.10 & 2.10 & 2.35 & 2.15 & 1.95 \\
\hline Ash, \% & 3.50 & 3.40 & 3.15 & 2.85 & 3.10 & 2.80 & 3.10 & 3.10 \\
\hline $\mathrm{Zn}, \mathrm{mg} \mathrm{Zn} / \mathrm{kg}$ & 66 & 77 & 134 & 241 & 308 & 154 & 256 & 318 \\
\hline
\end{tabular}

${ }^{1}$ Diets were fed in meal form from d 0 to 27 of the experiment. Basal diets contained $83 \mathrm{mg} \mathrm{Zn} / \mathrm{kg}$ from $\mathrm{ZnSO}_{4}$ provided by the trace mineral premix.

${ }^{2} \mathrm{RAC}=$ ractopamine $\mathrm{HC}^{\mathrm{l}}$.

${ }^{3} \mathrm{ZnAA}=\mathrm{Zn}$ AA complex (Availa-Zn; Zinpro, Eden Prairie, MN).

${ }^{4}$ Provided per kilogram of diet: 3,307 IU vitamin A, 413 IU vitamin $\mathrm{D}_{3}, 13 \mathrm{IU}$ vitamin E, $1.3 \mathrm{mg}$ vitamin $\mathrm{K}, 2.5 \mathrm{mg}$ riboflavin, $8.3 \mathrm{mg}$ pantothenic acid, $14.9 \mathrm{mg}$ niacin, and $0.01 \mathrm{mg}$ vitamin $\mathrm{B}_{12}$.

${ }^{5}$ Provided per kilogram of diet: $17 \mathrm{mg}$ Mn from manganese oxide, $55 \mathrm{mg}$ Fe from iron sulfate, $55 \mathrm{mg} \mathrm{Zn}$ from zinc sulfate, $8 \mathrm{mg}$ Cu from copper sulfate, $0.15 \mathrm{mg}$ I from calcium iodate, and $0.15 \mathrm{mg}$ Se from sodium selenite.

${ }^{6}$ Phyzyme 600 (Danisco Animal Nutrition, St. Louis, MO) provided 408 phytase units $/ \mathrm{kg}$ of feed, with a release of $0.1 \%$ available P.

${ }^{7}$ Provided $10 \mathrm{mg} / \mathrm{kg}$ of RAC (Paylean; Elanco Animal Health, Greenfield, IN).

${ }^{8} \mathrm{SID}=$ standardized ileal digestible.

$77 \mathrm{mg} \mathrm{Zn} / \mathrm{kg}$ in the control and RAC diets, respectively; 134, 241, and $308 \mathrm{mg} \mathrm{Zn/kg}$ in the diets containing added $\mathrm{ZnO}$; and 154,256 , and $318 \mathrm{mg} \mathrm{Zn} / \mathrm{kg}$ in the diets containing the added $\mathrm{ZnAA}$.

One pig was randomly selected from 16 pens per treatment (balanced across sex and group) for blood collection on $\mathrm{d} 0,8,18$, and 32 of the experiment and ileal mucosal swabs at harvest. On the final day of the experiment, pigs were harvested at 1 of 2 locations. The pigs that were selected for bleeding and 1 randomly selected pig from the remaining pens were weighed, individually tattooed, and shipped to the Kansas State University Meats Laboratory (Manhattan, KS) for harvest. The remaining pigs were weighed, tattooed, and shipped approximately $2.5 \mathrm{~h}$ to a commercial harvesting plant (Triumph Foods LLC, St. Joseph, MO).

Pigs harvested at the commercial packing plant were tattooed to allow individual identification for carcass data collection. Hot carcass weight was collected immediately following evisceration, and each carcass was evaluated for percent yield, backfat and loin depth, and percent lean. Fat and loin depth were 
collected using an optical probe (Fat-O-Meater; SFK Technology A/S, Henlev, Denmark) inserted between the 10th and 11th rib approximately $7 \mathrm{~cm}$ from the dorsal midline. Percent lean was calculated using equations from the National Pork Producers Council (2000).

Pigs harvested at the Kansas State University Meats Laboratory were tattooed to allow for individual carcass identification during data collection. Immediately following evisceration, $\mathrm{HCW}$ and liver weights were collected. In addition, liver samples were taken from the top left lobe for $\mathrm{Zn}$ analysis and mucosal swabs of the distal ileum were collected for mRNA expression analysis (Jones et al., 2014). After the visceral organ mass was removed, a $15-\mathrm{cm}$ segment of the ileum was collected $1 \mathrm{~m}$ proximal to the ileal-cecal junction. The ileum was cut along the mesenteric border, placed on a cold metal tray, and flushed with cold saline. A glass microscope slide was then used to collect scrapings of the mucosa's luminal surface. Mucosa scrapings were flash-frozen in liquid nitrogen and stored at $-80^{\circ} \mathrm{C}$ for later analyses. Carcasses were chilled $\left(-18^{\circ} \mathrm{C}\right)$ for $24 \mathrm{~h}$ and then the left side of each carcass was ribbed between the 10th and 11th rib interface. At this time, 10th rib backfat and loin depth were measured by trained university personnel using a ruler commonly used in non-computer-assisted carcass data collection. Fat thickness was measured three-fourths of the way up the loin muscle with the ruler perpendicular to the skin (National Pork Producers Council, 2000). The ruler was held perpendicular to the skin in the same location to measure the loin depth. Percent lean was calculated as previously described. A $30-\mathrm{cm}$ portion of the longissimus lumborum muscle (beginning at the 10th rib) from the left side of each pig was collected for immunohistochemical and fresh pork quality analysis. The results for the fresh pork quality analysis are reported in Paulk et al. (2014).

\section{Zinc Analysis}

Samples were collected via jugular venipuncture into heparinized (143 units of sodium heparin) vacutainer tubes (Tyco Health Care Group LP, Mansfield, MA), inverted, and immediately placed on ice until samples were processed. Whole blood was centrifuged $\left(2,000 \times g\right.$ for $15 \mathrm{~min}$ at $\left.4^{\circ} \mathrm{C}\right)$ and the plasma was removed and frozen at $-20^{\circ} \mathrm{C}$. Plasma was deproteinized by diluting $1: 4$ in $12.5 \%$ trichloroacetic acid followed by centrifugation at $2,000 \times g$ for $15 \mathrm{~min}$ at $4^{\circ} \mathrm{C}$ (GS-6KR; Beckman-Coulter, Brea, CA), with the resulting supernatant collected for analysis. Zinc analysis was determined by flame atomic absorption spectrophotometry according to the methods of Shaw et al. (2002; UNICAM 989 Solar AA Spectrometer; Thermo Elemental Corp., Franklin, MA).

Liver, loin, and feed samples were microwave digested (MARS 5; CEM Corp., Matthews, NC) in $10 \mathrm{~mL}$ of $\mathrm{HNO}_{3}$ followed by addition of $2 \mathrm{~mL}$ of $\mathrm{H}_{2} \mathrm{O}_{2}$ (Shaw et al., 2002). Samples were brought to constant volume and diluted appropriately for $\mathrm{Zn}$ analysis described previously.

\section{Ileal Mucosal Gene Expression}

Approximately $100 \mathrm{mg}$ of ileal mucosa was homogenized in Trizol (Life Technologies, Grand Island, NY) for the isolation of nucleic acids (Gonzalez et al., 2013). Extracted nucleic acids were purified using the Purelink RNA Mini kit (Life Technologies, Carlsbad, CA). Total RNA was collected with the addition of 90 $\mu \mathrm{L}$ of ribonuclease (RNase)-free water on the membrane for $1 \mathrm{~min}$ followed by centrifuging the column at $12,000 \times g$ for $2 \mathrm{~min}$ at room temperature. Total RNA concentration and quality (absorbance $[\mathbf{A}]$ ratio at 260 and $280 \mathrm{~nm}$ ) was quantified using a NanoDrop 1000 spectrophotometer (Thermo Scientific, Wilmington, DE). All extractions yielded RNA with A260:280 nm ratios greater than 1.9 and all samples possessed A260:230 nm ratios greater than 1.8. Extracted RNA was stored at $-80^{\circ} \mathrm{C}$ until PCR analysis.

Fifty nanograms of total RNA was treated to RNase-free deoxyribonuclease and then reverse transcribed to cDNA (High Capacity cDNA Archive kit; Life Technologies, Carlsbad, CA) in a $20-\mu \mathrm{L}$ reaction, according to the manufacturers' recommendations. Five nanogram equivalents of total RNA was amplified with gene-specific primers (Table 3), DNA polymerase, and SYBRGreen chemistry (PerfeCta Sybr fast mix; Quanta Biosciences, Gaithersburg, MD) in a Realplex ${ }^{2}$ S PCR System (Eppendorf North America, Hauppauge, NY). Thermal cycling parameters included an initial heating step of $50^{\circ} \mathrm{C}$ for $2 \mathrm{~min}$ and an initial denaturing step of $95^{\circ} \mathrm{C}$ for $10 \mathrm{~min}$ followed by 50 cycles of $15 \mathrm{~s}$ at $95.0^{\circ} \mathrm{C}$, an annealing step for $30 \mathrm{~s}$ at the appropriate temperature for each primer, and an extension step of $20 \mathrm{~s}$ at $68.0^{\circ} \mathrm{C}$. A final dissociation step was included at $95^{\circ} \mathrm{C}$ for $15 \mathrm{~s}$ followed by annealing at $60^{\circ} \mathrm{C}$ for $15 \mathrm{~s}$. Melting temperature analysis was then conducted between 60 and $95^{\circ} \mathrm{C}$ using a 20-min ramp time and continuous fluorescence detection to determine primer specificity for each reaction. Primer efficiencies were determined from the slope of varying input concentrations, with an acceptable range for amplification being -3.0 to -3.8 . All sequences and efficiencies can be found in Table 3. Sequencing of the amplicon products ensured that all primers amplified the gene of interest (University of California at 
Table 3. Sequences, annealing temperatures, amplicon length, and efficiency of primers used for real-time PCR quantification of gene expression

\begin{tabular}{|c|c|c|c|c|c|}
\hline Small intestine genes & Forward primer ( $5^{\prime}$ to $\left.3^{\prime}\right)$ & Reverse primer ( $5^{\prime}$ to $\left.3^{\prime}\right)$ & $\mathrm{T}_{\mathrm{m}},{ }^{\circ} \mathrm{C}$ & $\begin{array}{c}\text { Amplicon } \\
\text { length }\end{array}$ & Efficiency \\
\hline Interleukin-1 $\beta$ & СCTCCTCCCAGGCCTTCTGT & GGGCCAGCCAGCACTAGAGA & 62.0 & 178 & 1.01 \\
\hline Interleukin-8 & TCCTGCTTTCTGCAGCTCTC & GGGTGGAAAGGTGTGGAATG & 60.5 & 100 & 1.09 \\
\hline Tumor necrosis factor $\alpha$ & GCAGGAGCCACCACGCTCTT & CGTGGGCGACGGGCTTATCT & 62.0 & 147 & 0.90 \\
\hline \multicolumn{6}{|l|}{ Normalizing gene } \\
\hline Ribosomal protein L4 & AGGAGGCTGTTCTGCTTCTG & TCCAGGGATGTTTCTGAAGG & 60.5 & 184 & 1.06 \\
\hline
\end{tabular}

Davis, DNA Sequencing Facility, Davis, CA). Due to sample numbers and the need to conduct the PCR analysis for each gene over multiple plates, plates were balanced so that an equal number of treatments represented on each plate. Additionally, a pooled control sample representative of all treatment groups was run on each plate as an internal standard. Normalized expression $(\triangle \mathrm{Ct})$ for each sample was determined using Ribosomal protein L4 (RPL4) as an endogenous control gene. The average normalized expression of the pooled control sample was used as the calibrator to calculate relative gene expression (Livak and Schmittgen, 2001; McNeill et al., 2007). For each sample, relative expression was calculated as $2^{-\Delta \Delta \mathrm{Ct}}$ in which $\Delta \Delta \mathrm{Ct}$ represents $\Delta \mathrm{Ct}$ sample $-\Delta \mathrm{Ct}$ calibrator (Livak and Schmittgen, 2001).

\section{Statistical Analysis}

All growth performance, carcass characteristic, and relative gene expression data was analyzed as a generalized randomized complete block design using the MIXED procedure of SAS (SAS Inst. Inc.) with pen as the experimental unit for the growth performance and carcass characteristic data and selected pig within pen for the relative gene expression data. Dietary treatment served as the fixed effect while gender, group, and barn were included as random blocking factors. For plasma $\mathrm{Zn}$ concentration analysis, the statistical structure was the same except day of bleeding served as a fixed effect in addition to dietary treatment. Day of bleeding also served as the repeated measure with animal as the subject. Contrast statements consisted of 1) negative control vs. positive control RAC diet, 2) the 3-way and all possible 2-way interactions between increasing added $\mathrm{Zn}$ and source and day, 3) increasing $\mathrm{Zn}$ linear and quadratic polynomials, 4) added $\mathrm{Zn}$ from $\mathrm{ZnO}$ vs. from the $\mathrm{ZnAA}$, and 5) increasing day linear and quadratic polynomials. Statistical significance was determined at $P<0.05$ and $P$-values falling within $P>0.05$ and $P<0.10$ were considered a trend.

\section{RESULTS}

\section{Experiment 1}

Analyzed $\mathrm{Zn}$ concentrations were greater than the calculated levels for the control and RAC diets (Table 1; calculated concentrations equaled 103 and $107 \mathrm{mg} \mathrm{Zn/kg} \mathrm{and} \mathrm{analyzed} \mathrm{levels} \mathrm{equaled} 168$ and 131 $\mathrm{mg} \mathrm{Zn/kg}$, respectively). Analyzed $\mathrm{Zn}$ concentrations were within the acceptable limits for analytical variation according to the Association of American Feed Control Officials (2010) for the added $\mathrm{Zn}$ diets. There is no explanation for increased levels of analyzed $\mathrm{Zn}$ for the control and RAC diets; however, there were still increases in analyzed $\mathrm{Zn}$ content with increasing added $\mathrm{Zn}$ treatments.

From d 0 to 14 , pigs fed the RAC diet had improved $(P<0.05)$ ADG, G:F, and d-14 BW compared with pigs fed the control diet (Table 4). Increasing dietary $\mathrm{Zn}$ from $\mathrm{ZnO}$ tended to improve (linear, $P=$ 0.072) G:F. Pigs fed diets with RAC plus $50 \mathrm{mg} \mathrm{Zn/kg}$ from the ZnAA had increased $(P<0.05)$ ADG and G:F compared with pigs solely fed RAC. No differences in growth performance were observed among pigs fed diets containing $50 \mathrm{mg} \mathrm{Zn/kg}$ from $\mathrm{ZnO}$ or the $\mathrm{ZnAA}$.

From d 14 to 27, pigs fed the RAC diet had a tendency for increased $(P=0.060)$ ADG and reduced $(P=0.016)$ ADFI, resulting in improved $(P=0.001)$ $\mathrm{G}: \mathrm{F}$ compared with those fed the control diet. No differences were observed in performance when $\mathrm{Zn}$ from $\mathrm{ZnO}$ or the $\mathrm{ZnAA}$ was added to the RAC diet. Performance did not differ among pigs fed diets with $50 \mathrm{mg} \mathrm{Zn/kg} \mathrm{from} \mathrm{either} \mathrm{source.}$

Overall (d 0 to 27), pigs fed the RAC diet had improved $(P<0.05)$ ADG, G:F, final BW, HCW, and boneless loin weight. Pigs fed RAC also had a tendency for increased $(P=0.053)$ carcass yield and a tendency for reduced $(P=0.075)$ ADFI compared with those fed the control diet without RAC. Increasing $\mathrm{Zn}$ from $\mathrm{ZnO}$ tended to increase (linear, $P=0.067$ ) $\mathrm{G}: \mathrm{F}$ and boneless loin weights (quadratic, $P=0.064$ ). Pigs fed the diet with $50 \mathrm{mg} \mathrm{Zn/kg}$ from the $\mathrm{ZnAA}$ tended to have increased $(P=0.057)$ ADG compared with 
Table 4. Effects of added $\mathrm{Zn}$ and ractopamine $\mathrm{HCl}$ (RAC) on growth performance and carcass characteristics of finishing pigs, Exp. $1^{1}$

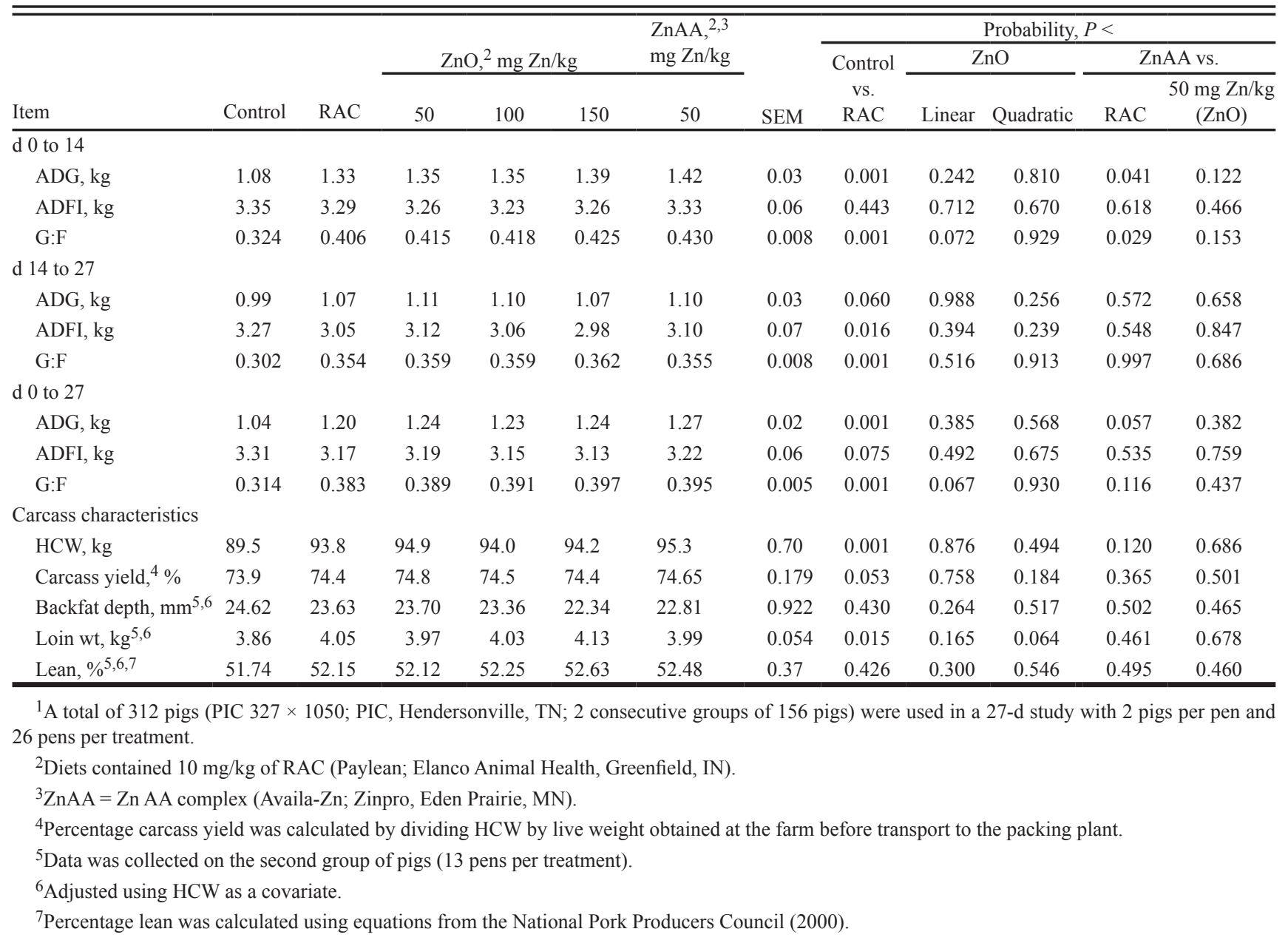

pigs fed the RAC diet. No differences were observed in performance between pigs fed diets with $50 \mathrm{mg} \mathrm{Zn} /$ $\mathrm{kg}$ from either source.

\section{Experiment 2}

Diet Analysis. Analyzed $\mathrm{Zn}$ levels for experimental diets are reported in Table 1. Analyzed Zn concentrations were within the acceptable limits for analytical variation according to the Association of American Feed Control Officials (2010)

Growth Performance and Carcass Characteristics. From d 0 to 14, pigs fed the RAC diet had improved $(P<0.05)$ ADG and G:F compared with pigs fed the control diet (Table 5). There were no interactions between $\mathrm{Zn}$ source and level or a $\mathrm{Zn}$ level or source main effect. There was a trend for increased $(P<0.10)$ $\mathrm{ADG}$ and ADFI in pigs fed diets with added $\mathrm{Zn}$ from $\mathrm{ZnO}$ compared with pigs fed diets with added $\mathrm{Zn}$ from the $\mathrm{ZnAA}$.

From d 14 to 35 and compared with pigs fed the control diet, pigs fed the RAC diet had improved $(P=$ $0.006) \mathrm{G}: \mathrm{F}$, which resulted from decreased $(P=0.011)$
ADFI. There were no Zn level $\times$ source interactions or a $\mathrm{Zn}$ level or source main effect for performance.

Overall (d 0 to 35), pigs fed the RAC diet had improved $(P<0.05)$ ADG, G:F, d 35 BW, HCW, loin depth, and percentage lean and reduced $(P<0.05)$ ADFI and backfat depth compared with those fed the control diet. There was no $\mathrm{Zn}$ level $\times$ source interaction or $\mathrm{Zn}$ level or source main effect for performance and carcass characteristics.

Plasma and Tissue Zn Levels and Liver Weights. Plasma $\mathrm{Zn}$ concentrations were not affected by the treatment $\times$ day interaction (Table 6 ). As day increased, there was an increase (quadratic, $P<0.001$ ) in plasma $\mathrm{Zn}$. On each of the plasma collection days, $\mathrm{Zn}$ concentration was not different between the RAC and control pigs. Also, there was no $\mathrm{Zn}$ level $\times$ source interaction or Zn source effect. However, pigs fed RAC diets with added $\mathrm{Zn}$ had increased (linear, $P<0.05$ ) plasma $\mathrm{Zn}$ concentrations on $\mathrm{d} 18$ and 32.

There was no difference in liver $\mathrm{Zn}$ concentrations between pigs fed either the RAC or control diet (Table 5). A Zn level $\times$ source interaction (quadratic, $P=0.007)$ was observed and this resulted from con- 
Table 5. Effects of level and source of added $\mathrm{Zn}$ on growth performance and carcass characteristics of finishing pigs fed ractopamine $\mathrm{HCl}(\mathrm{RAC})$, Exp. $2^{1}$

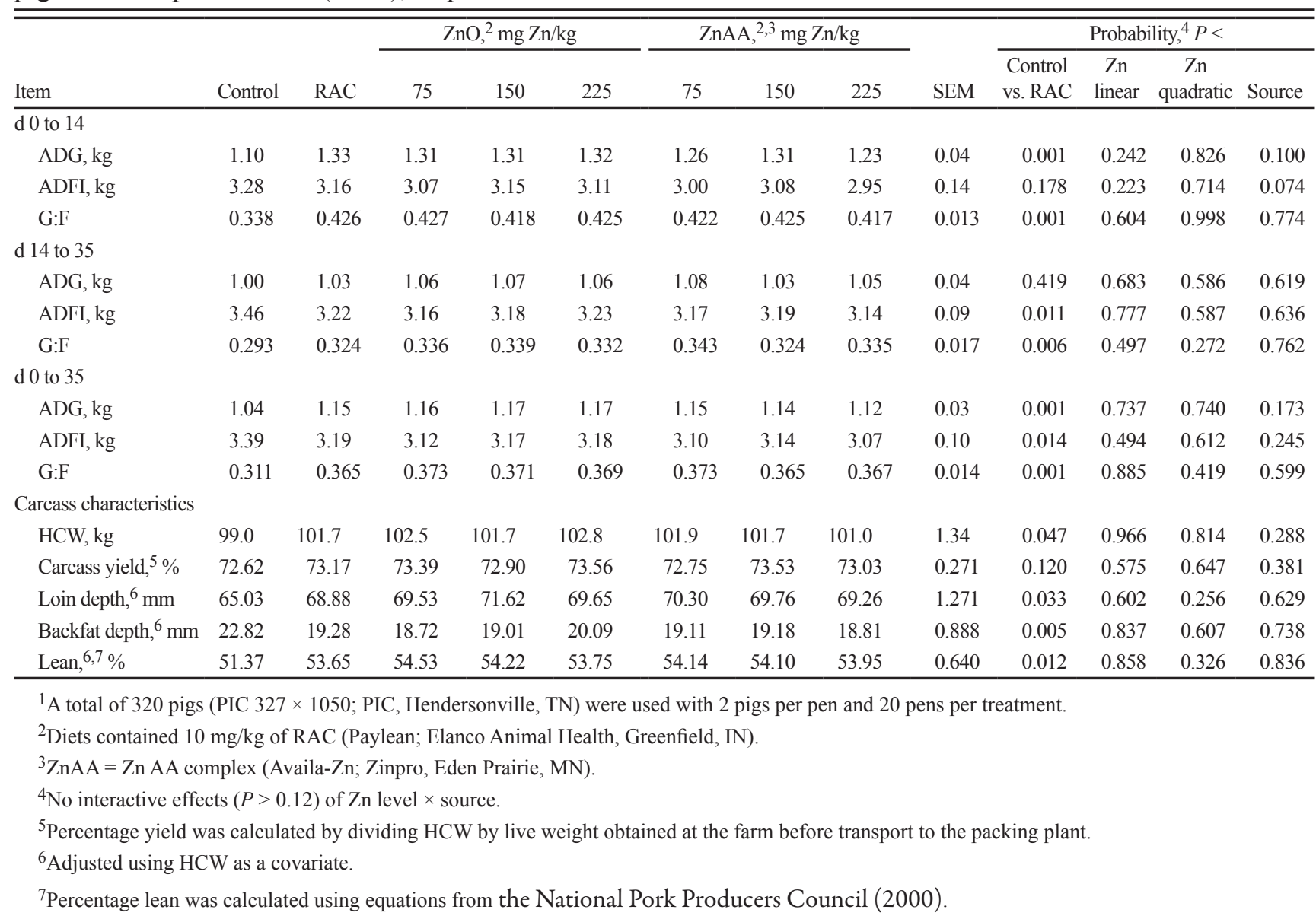

centrations plateauing at $150 \mathrm{mg} \mathrm{Zn/kg}$ for $\mathrm{ZnO}$ supplemented pigs and concentrations increasing linearly when the ZnAA was added. There were no treatment effects on loin $\mathrm{Zn}$ concentration.

Pigs fed the RAC diets without added $\mathrm{Zn}$ had increased $(P=0.028)$ liver weights compared with those fed the control diet (Table 6). There was no $\mathrm{Zn}$ level $\times$ source interaction or a $\mathrm{Zn}$ level effect for liver weight. Pigs fed the RAC diets with added $\mathrm{Zn}$ from $\mathrm{ZnO}$ tended to have heavier $(P=0.091)$ liver weights compared with pigs fed the RAC diet with added $\mathrm{Zn}$ from the $\mathrm{ZnAA}$.

Illeal Mucosal mRNA Expression. There was no $\mathrm{Zn}$ level $\times$ source interaction or a $\mathrm{Zn}$ source effect for $I L-1 \beta$ mRNA expression (Table 7). The expression of $I L-1 \beta$ was increased $(P=0.014)$ in mucosa of pigs fed the RAC diet compared with those fed the control diet. However, the relative mRNA expression of $I L-1 \beta$ decreased (linear; $P=0.026$ ) in the mucosa of pigs fed added $\mathrm{Zn}$. There were no treatment differences in $I L-8$ or $T N F-\alpha$ relative mRNA expression.

\section{DISCUSSION}

Both experiments consisted of a control diet without RAC and a RAC diet without added Zn. This allowed us to confirm the effects of the RAC diet on finishing pig performance and carcass characteristics independent of added Zn. Apple et al. (2007) summarized 23 publications determining the effects of RAC on performance and carcass characteristics of finishing pigs. They concluded that adding $10 \mathrm{mg} / \mathrm{kg}$ RAC to finishing pig diets resulted in a $11.7 \%, 13.3 \%, 2.4 \mathrm{~kg}$, and $3.5 \mathrm{~cm}^{2}$ average increase in ADG, G:F, HCW, and LM area, respectively, and a $1.4 \mathrm{~mm}$ reduction in 10th rib fat depth. In Exp. 1 conducted herein, improvements in $\mathrm{ADG}, \mathrm{G}: \mathrm{F}$, and $\mathrm{HCW}$ were greater than the average percentage improvement determined in the meta-analysis. However, values still fell within the range of differences observed. Similarly, RAC diets increased loin weight in Exp. 1. Although Apple et al. (2007) determined that RAC reduces 10th rib backfat thickness, it is not as consistent a response, with the change ranging from -16.1 to $6.6 \%$. Data from Exp. 1 did not show reductions in backfat thickness. In Exp. 2 conducted herein, improvements in ADG and HCW 
Table 6. Effects of level and source of added $\mathrm{Zn}$ on plasma, liver, and loin $\mathrm{Zn}$ concentrations and liver weights of finishing pigs fed ractopamine $\mathrm{HCl}$ (RAC), Exp. $2^{1}$

\begin{tabular}{|c|c|c|c|c|c|c|c|c|c|c|c|c|c|}
\hline \multirow[b]{2}{*}{ Item } & \multirow[b]{2}{*}{ Control } & \multirow[b]{2}{*}{ RAC } & \multicolumn{3}{|c|}{$\mathrm{ZnO}, \mathrm{mg} \mathrm{Zn} / \mathrm{kg}$} & \multicolumn{3}{|c|}{$\mathrm{ZnAA},{ }^{2} \mathrm{mg} \mathrm{Zn} / \mathrm{kg}$} & \multirow[b]{2}{*}{ SEM } & \multicolumn{4}{|c|}{ Probability, $P<$} \\
\hline & & & 75 & 150 & 225 & 75 & 150 & 225 & & $\begin{array}{c}\text { Control } \\
\text { vs. RAC }\end{array}$ & $\begin{array}{c}\mathrm{Zn} \\
\text { linear }\end{array}$ & $\begin{array}{c}\mathrm{Zn} \\
\text { quadratic }\end{array}$ & Source \\
\hline \multicolumn{14}{|c|}{ Plasma, ${ }^{3,4,5} \mu \mathrm{g} / \mathrm{mL}$} \\
\hline $\mathrm{d} 0$ & 1.06 & 1.01 & 1.04 & 1.05 & 1.04 & 1.01 & 1.06 & 1.06 & 0.038 & 0.328 & 0.248 & 0.743 & 0.845 \\
\hline d 8 & 1.08 & 1.07 & 1.09 & 1.06 & 1.15 & 1.08 & 1.11 & 1.16 & 0.046 & 0.920 & 0.114 & 0.395 & 0.512 \\
\hline d 18 & 1.13 & 1.06 & 1.12 & 1.16 & 1.11 & 1.10 & 1.18 & 1.17 & 0.039 & 0.159 & 0.023 & 0.157 & 0.441 \\
\hline d 32 & 1.08 & 1.01 & 1.07 & 1.07 & 1.13 & 1.07 & 1.09 & 1.13 & 0.039 & 0.187 & 0.005 & 0.981 & 0.769 \\
\hline \multicolumn{14}{|l|}{ DM basis, ${ }^{6} \mu \mathrm{g} / \mathrm{g}$} \\
\hline Liver $^{7}$ & 306.24 & 292.84 & 314.12 & 345.38 & 329.26 & 289.59 & 326.44 & 394.80 & 17.44 & 0.551 & 0.001 & 0.500 & 0.570 \\
\hline Loin 8 & 61.47 & 59.15 & 62.43 & 58.05 & 56.41 & 60.15 & 55.79 & 58.68 & 2.80 & 0.501 & 0.326 & 0.695 & 0.702 \\
\hline Liver wt, ${ }^{8,9} \mathrm{~kg}$ & 1.90 & 2.05 & 2.06 & 2.02 & 2.00 & 1.96 & 1.95 & 1.97 & 0.058 & 0.028 & 0.203 & 0.555 & 0.091 \\
\hline
\end{tabular}

${ }^{1}$ Diets contained $10 \mathrm{mg} / \mathrm{kg}$ of RAC (Paylean; Elanco Animal Health, Greenfield, IN).

${ }^{2} \mathrm{ZnAA}=\mathrm{Zn}$ AA complex (Availa-Zn; Zinpro, Eden Prairie, MN).

${ }^{3}$ Values represent 128 pigs, 1 pig randomly selected from 16 pens per treatment.

${ }^{4}$ No interactive effects $(P>0.212)$ of $\mathrm{Zn}$ level $\times$ source or treatment $\times$ day.

${ }^{5}$ There was an increase (quadratic, $P<0.001$ ) in plasma $\mathrm{Zn}$ from Day 0 to 18 .

${ }^{6}$ Values represent 160 pigs, 1 pig randomly selected from 20 pens per treatment.

${ }^{7}$ There was a $\mathrm{Zn}$ level $\times$ source interaction (quadratic, $P=0.007$ ).

${ }^{8}$ No interactive effects $(P>0.234)$ of $\mathrm{Zn}$ level $\times$ source.

${ }^{9}$ Liver weights were measured with the gallbladder still intact.

were similar to the average improvement determined in the meta-analysis. Improvements in G:F and reductions in backfat depth were greater than the average. However, values still fell within the range of differences observed. Similarly, RAC diets increased loin depth in Exp. 2.

The NRC (2012) has a Zn requirement estimate of $50 \mathrm{mg} \mathrm{Zn/kg} \mathrm{for} \mathrm{growing} \mathrm{pigs} \mathrm{from} 100$ to $135 \mathrm{~kg} \mathrm{BW}$. Although the NRC (2012) estimates increased requirements of AA for 115 to $135 \mathrm{~kg}$ pigs when RAC is added to the diet, there is not a similar increase in the $\mathrm{Zn}$ requirement estimate. However, recent data might suggest otherwise, as Fry et al. (2013) observed a tendency for improved $\mathrm{G}: \mathrm{F}$ in finishing pigs fed diets containing $5 \mathrm{mg} / \mathrm{kg}$ RAC (with $79 \mathrm{mg} \mathrm{Zn} / \mathrm{kg}$ from the trace mineral premix) with $40 \mathrm{mg} \mathrm{Zn} / \mathrm{kg}$ from either $\mathrm{ZnSO}_{4}$ or the ZnAA. Our results from Exp. 1 agree with Fry et al. (2013) in that the addition of up to $150 \mathrm{mg} \mathrm{Zn/kg}$ from $\mathrm{ZnO}$ tended to improve $\mathrm{G}: \mathrm{F}$ in finishing pigs fed diets containing RAC. However, data from Exp. 2 did not support this observation as performance was not influenced by increasing level of added $\mathrm{Zn}$. Although Fry et al. (2013) determined that added Zn may enhance the response to RAC, they also reported 2 additional experiments in which they did not observe improved performance when $\mathrm{Zn}$ was added to RAC diets (with 79 $\mathrm{mg} \mathrm{Zn} / \mathrm{kg}$ from the trace mineral premix). Other studies have also failed to demonstrate improvements in the response to RAC when supplemental $\mathrm{Zn}$ was added at levels above that contributed in the trace mineral premix (Rambo, 2013; Gowanlock et al., 2013).
Previous research demonstrated improved ADG in pigs fed RAC diets with $50 \mathrm{mg} \mathrm{Zn} / \mathrm{kg}$ from the $\mathrm{ZnAA}$ compared with supplementing different inorganic $\mathrm{Zn}$ sources (Patience et al., 2011; Rambo et al., 2012). However, these studies did not include a RAC treatment without added $\mathrm{Zn}$. Therefore, it is not possible to determine if the supplemental $\mathrm{Zn}$ elicited additional benefits over that observed from a diet containing only RAC. Both of the experiments herein did not indicate a difference in performance and carcass characteristics among finishing pigs supplemented $\mathrm{Zn}$ from $\mathrm{ZnO}$ vs. from the ZnAA. This is similar to observations of Fry et al. (2013) and Rambo (2013). In attempt to explain the variability in the response to added $\mathrm{Zn}$ from the ZnAA vs. inorganic Zn, Patience et al. (2013) conducted an experiment to determine if the Lys:calorie ratio of a finishing pig diet with RAC could affect the response to different added $\mathrm{Zn}$ sources. They observed no difference in performance of pigs fed added $\mathrm{Zn}$ independent of the Lys:calorie ratio.

If growth is the primary response criterion used to establish $\mathrm{Zn}$ requirements in finishing pigs fed RAC diets, then the $\mathrm{Zn}$ provided by the premix $(83 \mathrm{mg} \mathrm{Zn} /$ $\mathrm{kg}$ from $\mathrm{ZnSO}_{4}$ ) and endogenous $\mathrm{Zn}$ from the ingredients may not have been sufficient for pigs in Exp. 1. However, $\mathrm{Zn}$ provided by the premix $(55 \mathrm{mg} \mathrm{Zn} /$ $\mathrm{kg}$ from $\mathrm{ZnSO}_{4}$ ) and endogenous $\mathrm{Zn}$ from the ingredients was sufficient to support maximum performance in Exp. 2. The results from the 2 experiments were inconsistent and do not provide a clear conclusion for $\mathrm{Zn}$ concentrations in RAC-containing diets fed to fin- 
Table 7. Effects of level and source of added $\mathrm{Zn}$ on mRNA expression of inflammatory cytokine genes in the distal ileum of finishing pigs fed ractopamine $\mathrm{HCl}$ (RAC), Exp. 21,2

\begin{tabular}{|c|c|c|c|c|c|c|c|c|c|c|c|c|c|}
\hline \multirow[b]{2}{*}{ Item $^{3}$} & \multirow[b]{2}{*}{ Control } & \multirow[b]{2}{*}{ RAC } & \multicolumn{3}{|c|}{$\mathrm{ZnO},{ }^{4} \mathrm{mg} \mathrm{Zn} / \mathrm{kg}$} & \multicolumn{3}{|c|}{$\mathrm{ZnAA},{ }^{4,5} \mathrm{mg} \mathrm{Zn} / \mathrm{kg}$} & \multirow[b]{2}{*}{ SEM } & \multicolumn{4}{|c|}{ Probability, ${ }^{6} P<$} \\
\hline & & & 75 & 150 & 225 & 75 & 150 & 225 & & $\begin{array}{c}\text { Control } \\
\text { vs. RAC }\end{array}$ & $\mathrm{Zn}$ linear & $\begin{array}{l}\text { Zn qua- } \\
\text { dratic }\end{array}$ & Source \\
\hline$\overline{I L-1 \beta}$ & 4.62 & 10.12 & 5.63 & 7.62 & 5.54 & 5.74 & 4.91 & 5.61 & 1.776 & 0.014 & 0.026 & 0.122 & 0.498 \\
\hline$I L-8$ & 3.84 & 3.75 & 4.82 & 4.53 & 3.90 & 3.94 & 3.10 & 3.65 & 1.867 & 0.942 & 0.881 & 0.621 & 0.233 \\
\hline$T N F-\alpha$ & 7.22 & 6.65 & 7.20 & 5.95 & 6.00 & 6.15 & 5.87 & 4.82 & 1.305 & 0.727 & 0.302 & 0.769 & 0.414 \\
\hline
\end{tabular}

ishing pigs. Published data has also provided inconsistent results and has not explained the variability of this response through the factorial arrangement of treatments. However, research has suggested that the requirement for $\mathrm{Zn}$ may be greater for immune response when animals are stressed (Klasing, 1992). In addition, Rambo (2013) attributed the inconsistency of obtained results to health status of the pigs used.

Ractopamine is a member of the phenylethanolamine class of $\beta$-adrenergic agonists, which are structurally and functionally similar to the endogenous catecholamines, epinephrine and norepinephrine (Barnes, 1995; Beermann, 2002). These compounds act as repartitioning agents directing nutrients toward skeletal muscle accretion and away from adipose tissue deposition (Beermann, 2002; Mersmann, 1998). This was demonstrated in Exp. 2 through increased loin depth and reduced backfat thickness. In addition, the data indicated that the RAC diet increased the relative expression of proinflammatory cytokine $I L-1 \beta$ in distal ileum mucosa of pigs compared with those fed the control diet. Increasing interleukin- $1 \beta$ is correlated with elevated intestinal inflammation (Reinecker et al., 1991) and is also associated with increases in intestinal tight junction permeability (Al-Sadi and Ma, 2007). Therefore, our data would suggest that feeding RAC diets results in elevated inflammation of the pig's small intestine based on increased relative expression of $I L-1 \beta$. To the best of our knowledge, there has been no previous data that demonstrates the effects of RAC diets on the relative expression of proinflammatory cytokines in the small intestines of pigs. However, the response to other $\beta$-agonist and endogenous catecholamines on proinflammatory cytokine expression in various tissues has been studied. Research in mice also determined that catecholamines released from the sympathetic nerve terminals and adrenal gland re- sulted in increased $I L-1 \beta$ expression in the liver and spleen (Jung et al., 2000).

Although there were increases in $I L-1 \beta$ in our study, there were no differences in relative expression of proinflammatory cytokines $T N F-\alpha$ or $I L-8$. Verghese et al. (1994) evaluated different cyclic adenosine monophosphate (cAMP)-phosphodiesterase isoforms that inhibited degradation of cAMP to determine if these isoforms could regulate cytokine release from lipopolysaccharide (LPS)-challenged human monocytes. The authors concluded that increasing cellular levels of cAMP reduced the accumulation of $T N F-\alpha$ gene expression. However, they increased accumulation of $I L-1 \beta$ mRNA. Additional research has also determined that increasing cAMP can inhibit LPS-induced production of $T N F-\alpha$ and $I L-8$ in human promonocytic THP-1 cells (Farmer and Pugin, 2000). When feeding the $\beta$-adrenergic agonist RAC, it binds to a $\beta$-adrenergic receptor, which activates intracellular adenylyl cyclase, leading to increases in intracellular levels of cAMP (Mersmann, 1998). Therefore, increasing intracellular cAMP by feeding RAC may explain the observed differences in $I L-1 \beta$ but not $T N F-\alpha$ and $I L-8$ in the current experiment.

Although pigs fed RAC had increased relative expression of the proinflammatory cytokine $I L-1 \beta$ in the distal ileum mucosa, increasing $\mathrm{Zn}$ in $\mathrm{RAC}$ diets reduced the relative expression of $I L-1 \beta$. Previous data conducted in vitro has determined that $\mathrm{Zn}$ deficiency increased gene expression of $I L-1 \beta, T N F-\alpha$, and $I L-8$ in the monocyte-macrophage cell line (Bao et al., 2003). The authors reported that the reduction in these proinflammatory cytokines due to added $\mathrm{Zn}$ is not clearly defined. They speculated that the mechanism revolves around the increase in a $\mathrm{Zn}$ finger protein, A20, when increasing levels of $\mathrm{Zn}$ are added to the cell media. Jaattela et al. (1996) determined that 
A20 protein prevents an increase in the expression of $I L-1$ and $T N F-\alpha$ by inhibiting the activation of nuclear factor- $\kappa \beta$-like transcription factors.

\section{Conclusion}

Adding $\mathrm{Zn}$ to diets containing $\mathrm{RAC}$ resulted in a trend for improved performance of pigs in 1 of 2 experiments. Therefore, adding $\mathrm{Zn}$ to diets containing RAC may improve finishing pig performance. However, the results are inconsistent. Due to the decrease in relative expression of $I L-1 \beta$, we speculate that the variability of the response in pigs fed RAC diets with added $\mathrm{Zn}$ is mediated at the intestinal level and variability in the response may possibly be due to levels of stressors present in the environment. Therefore, more research is warranted to better define the relationship between RAC, $\mathrm{Zn}$, and intestinal inflammation.

\section{LITERATURE CITED}

Al-Sadi, R. M., and T. Y. Ma. 2007. IL-1 $\beta$ causes an increase in intestinal epithelial tight junction permeability. J. Immunol. 178:4641-4649.

Apple, J. K., P. J. Rincker, F. K. McKeith, S. N. Carr, T. A. Armstrong, and P. D. Matzat. 2007. Review: Meta-analysis of the ractopamine response in finishing swine. Prof. Anim. Sci. 23:179-196.

AOAC. 2006. Official methods of analysis. 18th ed. AOAC Int., Washington, DC.

AOAC. 2012. Official methods of analysis. 19th ed. AOAC Int., Gaithersburg, MD.

Association of American Feed Control Officials. 2010. Official publication. Assoc. Am. Feed Control Off., Inc., Oxford, IN.

Baggiolini, M., and I. Clark-Lewis. 1992. Interleukin-8, a chemotactic and inflammatory cytokine. FEBS Lett. 307:97-101.

Bao, B., A. S. Prasad, F. W. J. Beck, and M. Godmere. 2003. Zinc modulates mRNA levels of cytokines. Am. J. Physiol. Endocrinol. Metab. 285:E1095-E1102.

Barnes, P. J. 1995. Beta-adrenergic receptors and their regulation. Am. J. Respir. Crit. Care Med. 152:838-860.

Beermann, D. H. 2002. Beta-adrenergic receptor agonist modulation of skeletal muscle growth. J. Anim. Sci. 80:E18-E23.

Farmer, P., and J. Pugin. 2000. $\beta$-Adrenergic agonists exert their "anti-inflammatory" effects in monocytic cells through the $\mathrm{I}_{\mathrm{k}} \mathrm{B} / \mathrm{NF}_{\mathrm{k}} \mathrm{B}$ pathway. Am. J. Physiol. Lung Cell. Mol. Physiol. 279:L675-L682.

Fry, S., W. Hu, N. Paton, and D. Cook. 2013. Effect of dietary zinc level and source and ractopamine level on performance and carcass traits of finishing pigs. J. Anim. Sci. 91(Suppl. 2):O231 (Abstr.).

Gonzalez, J. M., L. E. Camacho, S. M. Ebarb, K. C. Swanson, K. A. Vonnahme, A. M. Stelzleni, and S. E. Johnson. 2013. Realimentation of nutrient restricted pregnant beef cows supports compensatory fetal muscle growth. J. Anim. Sci. 91:4797-4806.

Gowanlock, D. W., D. C. Mahan, J. S. Jolliff, S. J. Moeller, and G. M. Hill. 2013. Evaluating the NRC levels of $\mathrm{Cu}, \mathrm{Fe}, \mathrm{Mn}$, and $\mathrm{Zn}$ using organic minerals for grower-finisher swine. J. Anim. Sci. 91:5680-5686.
Jaattela, M., H. Mouritzen, F. Elling, and L. Bastholm. 1996. A20 zinc finger protein inhibits TNF and IL-1 signaling. J. Immunol. 156:1166-1173.

Jones, C. K., D. M. Madson, R. G. Main, N. K. Gabler, and J. F. Patience. 2014. Poor weaning transition average daily gain in pigs is not correlated with pathological or immunological markers of enteric disease during a porcine reproductive and respiratory syndrome virus outbreak. J. Anim. Sci. 92:2568-2577.

Jung, B. D., K. Kimura, H. Kitamura, K. Makondo, K. Kanehira, and M. Saito. 2000. Sympathetic activation of hepatic and splenic IL-1 $\beta$ mRNA expression during oscillation stress in the rat. J. Vet. Med. Sci. 62:409-413.

Klasing, K. C. 1992. Nutrition and immunity. What is known about feeding animals for optimum immunocompetence? Large Anim. Vet. 47:16.

Livak, K. J., and T. D. Schmittgen. 2001. Analysis of relative gene expression data using real-time quantitative PCR and the 2($\Delta \Delta \mathrm{CT}$ ) method. Methods 25:402-408.

Ma, T. Y., G. K. Iwamoto, N. T. Hoa, V. Akotia, A. Pedram, M. A. Boivin, and H. M. Said. 2004. TNF- $\alpha$-induced increase in intestinal epithelial tight junction permeability requires NF- $k \mathrm{~B}$ activation. Am. J. Physiol. 286:G367-G376.

McNeill, R. E., N. Miller, and M. J. Kerin. 2007. Evaluation and validation of candidate endogenous control genes for realtime quantitative PCR studies of breast cancer. BMC Mol. Biol. 8:107.

Mersmann, H. J. 1998. Overview of the effects of $\beta$-adrenergic receptor agonists on animal growth including mechanisms of action. J. Anim. Sci. 76:160-172.

National Pork Producers Council. 2000. Prediction equations. In: E. Berg, editor, Pork composition and quality assessment procedures. Des Moines, IA. p. 19.

NRC. 2012. Nutrient requirements of swine. 11th rev. ed. Natl. Acad. Press, Washington, DC.

Patience, J. F., A. Chipman, T. L. Ward, and M. E. Wilson. 2011. Impact of zinc source on grow-finish performance, carcass composition and locomotion score. J. Anim. Sci. 89(E-Suppl. 2):178 (Abstr.).

Patience, J. F., A. Chipman, and M. Wilson. 2013. The effect of lysine:calorie ratio on the response to zinc supplementation in late finishing diets containing ractopamine. J. Anim. Sci. 91(Suppl. 2):O232 (Abstr.).

Paulk, C. B., M. D. Tokach, J. L. Nelssen, D. D. Burnett, M. A. Vaughn, K. J. Phelps, S. S. Dritz, J. M. DeRouchey, R. D. Goodband, J. C. Woodworth, T. A. Houser, K. D. Haydon, and J. M. Gonzalez. 2014. Effect of dietary zinc and ractopamine$\mathrm{HCl}$ on pork chop muscle fiber type distribution, tenderness, and color characteristics. J. Anim. Sci. 92:2325-2335.

Rambo, Z. J. 2013. Effects of supplemental zinc and ractopamine on growth performance, carcass composition, and skeletal muscle synthesis and gene expression in finishing pigs. PhD Diss. Purdue Univ., West Lafayette, IN.

Rambo, Z., A. Schinckel, M. Wilson, T. Ward, and B. Richert. 2012. Effect of supplemental zinc source and ractopamine on grow-finish pig growth performance and carcass characteristics. J. Anim. Sci. 90(Suppl. 2):71 (Abstr.).

Reinecker, H. C., M. Steffen, C. Doehn, J. Petersen, I. Pfluger, A. Voss, and A. Raedler. 1991. Proinflammatory cytokines in intestinal mucosa. Immunol. Res. 10:247-248.

Shankar, A. H., and A. S. Prasad. 1998. Zinc and immune function: The biological basis of altered resistance to infection. Am. J. Clin. Nutr. 68(Suppl):447S-463S. 
Shaw, D. T., D. W. Rozeboom, G. M. Hill, A. M. Booren, and J. E. Link. 2002. Impact of vitamin and mineral supplement withdrawal and wheat middling inclusion on finishing pig growth performance, fecal mineral concentration, carcass characteristics, and the nutrient content and oxidative stability of pork. J. Anim. Sci. 80:2920-2930.
Verghese, M. W., R. T. Mcconnell, A. B. Strickland, R. C. Gooding, S. A. Stimpson, D. P. Yarnall, J. D. Taylor, and P. J. Furdon. 1994. Differential regulation of human monocyte-derived TNF- $\alpha$ and IL- $1 \beta$ by type IV cAMP-phosphodiesterase (cAMP-PDE) inhibitors. J. Pharmacol. Exp. Ther. 272:1313-1320. 